\title{
Penguatan Peran Penyuluh Agama Sebagai Mediator Non Ajudikasi terhadap Pihak Sengketa
}

\author{
Laili Asyiqoh, Hari Syamhari, Siti Fatimah \\ IAIN Madura \\ Email : lailiasiqoh@gmail.com
}

\begin{abstract}
Courts are not the only media to resolve cases for the parties to the dispute. There are still other ways out of court that are actually more appropriate and quick to resolve cases of dispute and / or crime, is mediation. In the Religious Courts have also been introduced to mediation to further enhance the peace efforts that have been undertaken to improve broken family relationships (want to separate / talaq). One of the alternatives presented in solving a divorce case is based on a win-win solution. The problem to be studied in this article is how the duties and responsibilities of religious instructors in carrying out their profession to provide advocacy, mentoring, and mediate non ajudikasi based on the principle of help-help, cling to the source of Islamic teachings. Second, the role of religious counselor in the mediation of divorce dispute cases should be competent, so that no party is harmed.
\end{abstract}

Abstrak: Pengelolan Pengadilan bukan satu-satunya media untuk menyelesaikan perkara bagi para pihak yangbersengketa. Masih ada cara lain di luar pengadilan yang sebenarnya lebih tepat dan cepat untukmenyelesaikan kasus sengketa dan atau kriminal, yaitu mediasi. Di PengadilanAgama juga telah diperkenalkan dengan mediasi guna lebih meningkatkanupaya-upaya damai yang selama ini dijalankan untuk memperbaiki hubungankeluarga yang sedang retak (ingin berpisah/talaq).Salah satu alternatif yang disuguhkan dalam menyelesaikan perkara perceraian adalah berdasarkan pada konsep sama-sama menang (win-win solution). Permasalahan yang akan dikaji dalam artikel ini adalah bagaimana tugas dan tanggung jawab penyuluh agama dalam menjalankan profesinya untuk memberikan advokasi ,pendampingan, dan menjadi mediator non ajudikasi berdasarkan pada prinsip tolong-menolong, berpegang teguh pada sumber ajaran agama Islam. Kedua, peran penyuluh agama dalam mediasi perkara sengketa perceraian sebaiknya harus kompeten, sehingga tidak ada pihak yang dirugikan.

Kata Kunci: Penyuluh Agama, Mediator Non Ajudikasi, Pihak Sengketa. 


\section{PENDAHULUAN}

Upaya yang bisa dilakukan dalam penyelesaian sengketa, salah satunya adalah mediasi. Mediasi adalah proses penyelesaian sengketa oleh penengah sebagai mediator dengan tujuan menyelesaikan sengketa dengan jalur damai. Dalam ajaran Islam istilah mediasi dikenal dengan istilah ishlah. Ishlahadalah suatu akad yang menghasilkan perdamaian atau suatu akad dengan maksud untuk mengakhiri suatu persengketaan antara dua pihak yang saling bersengketa (Salim, 2004: 5). Sebagai landasan, hal ini disampaikan oleh Allah dalam alQur'an, surat al-Nisa' (4): 35 yang berbunyi:

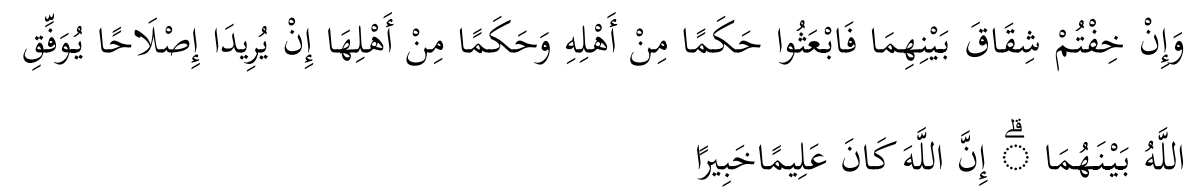

"Dan jika kamu khawatirkan ada persengketaan antara keduanya, maka kirimlah seorang hakam dari keluarga laki-laki dan seorang hakam dari keluarga perempuan. Jika kedua orang hakam itu bemaksud mengadakan perbaikan, niscaya Allah memberi taufik kepada suami istri itu. Sesungguhnya Allah Maha Mengetahui lagi Maha Mengenal. (QS al-Nisa' (4): 35)

Perlu diketahui bersama penyelesaian sengketa tidak harus melalui jalur hukum. Masih ada cara lain di luar pengadilan yang sebenarnya lebih tepat dan cepat untuk menyelesaikan kasus sengketa dan atau kriminal, yaitu mediasi. Penyelesaian sengketa, tidak selalu dilaksanakan dengan persidangan pengadilan, akan tetapi cara-cara damai dapat ditempuh dan diupayakan secara lebih efektif dan efisien dengan lembaga damai (dading) yang di atur dalam pasal $130 \mathrm{HIR} /$ pasal 195 RBG. Pasal ini merupakan pasal yang lebih mengefektifkan serta meningkatkan manfaat dari kebijakan pembaharuan peradilan. Bahkan kebijakan ini diperluas, dengan mendorong pengembangan mediasi pada umumnya. Pengembangan pasal $130 \mathrm{HIR} /$ Pasal 195 RBG dikonstruksikan sebagai mediasi oleh pengadilan yang akan menjadi dasar pengembangan Court Connected Mediation (Jacqueline, 1992: 56).

Peran Penyuluh Agama penting untuk mendamaikan kedua belah pihak yang bersengketa. Praktek semacam ini tidaklah bertentangan dengan tujuan atau fungsi hukum seperti fungsi memulihkan ketenteraman, memelihara perdamaian dalam masyarakat. Karena itu sangat baik atau tetap dijalankan. Lebih dari itu, upaya damai semacam ini harus membawa konsekuensi hukum yaitu menutup perkara begitu dicapai perdamaian. 
Doktrin yang mengatakan: sifat pidana tidak hapus sehingga perkara akan tetap diteruskan walaupun ada perdamaian, mestinya harus dihapuskan. Dapat saja, sifat pidana tidak hapus, tetapi perdamaian menghilangkan atau menghapus hak menuntut (memperkarakan). Perdamaian untuk sesuatu perbuatan pidana dapat disebut sebagai abolisi sosial seperti abolisi yang ada pada presiden (lazim dimasukkan sebagai hak preogratif Presiden). Tentu saja ada perbuatanperbuatan pidana tertentu yang tertutup untuk diselesaikan secara damai yaitu perbuatan pidana yang berkaitan dengan keamanan negara (national security) atau kepentingan nasional (national interest), atau kejahatan terhadap pejabat negara. Meminjam ajaran Rescoe Pound, (walaupun dalam konteks yang berbeda), kejahatan semacam ini dapat disebut sebagai kejahatan yang menyangkut public interest, berbeda dengan social interest (Harahap, 1997: 20).

Mediasi merupakan salah satu alternatif penyelesaian sengketa (APS) yang menggunakan pendekatan win-win solution dengan proses dan cara yang lebih sederhana dalam rangka memberikan akses keadilan yang lebih memuaskan kepada para pihak dengan menggunakan bantuan seorang mediator sebagai penampung aspirasi dalam upaya menemukan penyelesaian sengketa uang terbagi bagi kedua belah pihak (Witanto, 2011: 24).

Dalam penelitian ini penulis menggunakan metode penelitian pustaka atau yang biasa dikenal sebagai library research, yaitu dengan cara mengkaji sumber kepustakaan yang dalam hal ini berupa literature, buku-buku, kitab-kitab, dan dokumen yang berkaitan dengan pembahasan penelitian ini (Suryabrata, 2005: 75). Penelitian ini bersifat deskriptif-analitik yaitu menggambarkan secara obyektif tentang obyek penelitian peneliti dengan cara mengumpulkan data-data, kemudian menganalisa dengan kerangka pemikiran yang telah disusun dengan cermat dan terarah dan dengan tujuan untuk mengetahui dan menjelaskan obyek penelitian (Soekamto, 1988: 20-21).

Sedangkan jenis penelitian ini menggunakan content analysis (analisis isi) yaitu analisis aktivitas atau mengumpulkan dan menganalisis informasi, yakni dengan menganalisa dokumen-dokumen yang berkaitan langsung dengan Penyuluh Agama sebagai mediator non ajudikasi terhadap pihak sengketa.Peran Penyuluh Agama sangat dibutuhkan. Sebab dalam menyelesaikan perkara perceraian tidak butuh sembarang orang untuk menjalankan fungsi hakam atau mediator. Melainkan butuh orang atau hakam yang benar-benar mempunyai kompetensi khusus. 


\section{KONSEP MEDIASI DALAM TEORI DAN PRAKTEK}

Mediasi merupakan salah satu bentuk penyelesaian konflik yang orientasinya berdasarkan kesepakatan semua pihak. Mediasi ini merupakan tuntutan masyarakat akan terselesaikannya konflik dalam waktu yang cepat, tepat dan sesuai dengan harapan pihak yang bertikai (Usman, 2012: 3). Secara bahasa, mediasi berasal dari kata mediare yang artinya berada di tengah. Mediasi secara istilah adalah proses dimana pihak yang bertikai ditengahi oleh pihak ketiga melakukan penyelesaian masalah dan mempertimbangkan alternatif dan upaya guna mencapaisebuah kesepakatan (Muslih, 2007: 106).

Keberhasilan mediasi tergantung kepada beberapa hal, Di antaranya kualitas mediator (orang yang melakukan mediasi), usaha untuk mufakat dari pihak yang sedang bertikai, kepercayaan terhadap mediator dan kepercayaan terhadap masing-masing pihak. Sikap yang harus dimiliki oleh mediator antara lain terbuka, mandiri, netral, percaya diri, menghormati orang lain, seimbang, mempunyai komitmen, fleksibel, bisa memimpin proses mediasi denganbaik, percaya pada orang lain dan bisa dipercaya orang lain serta berorientasi pada pelayanan (Muslih, 2007: 107).

Ada empat macam model mediasi, yaitu pertama, Settlement mediation, yaitu mediasi yang bertujuan untuk mendorong terjadinya kompromi dari tuntutan kedua belah pihak yang bertikai(disputants). Kedua, Facilitative mediation, yaitu mediasi yang bertujuan untuk menghindarkan disputants dari posisi mereka danmenegosiasikan kebutuhan dan kepentingan mereka daripada memperjuangkan hak sah mereka secara kaku. Ketiga, Transformative mediation, yaitu mediasi yang menekankan untuk mencaripenyebab yang melatarbelakangi munculnya permasalahan di antara disputants berdasarkan isu relasi atau hubungan melalui pemberdayaan dan pengakuan. Keempat, Evaluative mediation, yaitu mediasi yang ditujukan untuk mencari kesepakatan berdasarkan hak sah disputants dalam wilayah yang diantisipasi pengadilan (Muslih, 2007: 109).

Adapun prinsip-prinsip mediasi ada lima, yaitu kerahasiaan (dari pertemuan dan isi mediasi), kesukarelaan (tidak ada paksaan dari pihak luar), pemberdayaan (atas kemampuan negosiasimasalah), netralitas (mediator adalah fasilitator) dan solusi yang unik (solusi tidak harus sesuai standar legal) (Muslih, 2007: 110).

Mediasi ini dilakukan dalam enam tahap, yaituTahap I adalah mediator setuju untuk menengahi disputants, Tahap II adalah mediator menghimpun sudut pandang disputants, Tahap III adalah memusatkan perhatian pada kebutuhan disputants dengan mengajak berdialog atas permasalahan dan kebutuhan mereka, Tahap IV adalah menciptakan pilihan terbaik (win-win options), Tahap V adalah mengevaluasi pilihan (evaluate options) untuk memastikan konflik dari pihak yang 
bertikai sudah ditemukan penyelesaiannya, Tahap VI adalah menciptakan kesepakatan(create an agreement) untuk memberikan solusi dalam rumusan yang sejelas mungkin, mengontrol dan mengawasi kesepakatan dalam mediasi. Sedangkan teknik mediasi secara berurutan adalah membukanya dengan perkenalan, penuturan cerita, klarifikasi permasalahandan kebutuhan, menyelesaikan masalah dan merancang kesepakatan (Muslih, 2007: 111).

Penyelesaian perkara atau sengketa melalui perdamaian mengandung berbagai keuntungan substansial dan psikologis. Di antaranya adalah penyelesaiannya bersifat informal, diselesaikan oleh para pihak yang bertikai sendiri, jangka waktu penyelesaiannya pendek, biaya ringan, tidak perlu pembuktian, kooperatif, bebas emosi dan dendam, komunikasi dan fokus penyelesaian, win-win solution dan penyelesaiannya bersifat konfidensial (Taufiq, 2014).

\section{PERAN PENYULUH AGAMA DALAM MELAKUKAN MEDIASI}

Penyuluh Agama adalah Pegawai Negeri Sipil yang diberi tugas, tanggungjawab dan wewenang secara penuh oleh Pejabat yang berwenang untuk melakukan kegiatan bimbingan keagamaan dan penyuluhan pembangunan melalui bahasa agama (Bidang Penais Zakat dan Wakaf, 2003: 2). Dalam KMA No. 516 Tahun 2003 tentang tugas pokok dan fungsi penyuluh secara umum adalah melaksanakan dan mengembangkan kegiatan bimbingan/penyuluhan agama dan pembangunan melalui bahasa agama. Kalau dirinci dapat dipahami tugas penyuluh yaitu memberikan informasi, edukasi, konsultasi, advokasi serta memberikan arahan dalam peningkatan ketaqwaan dan kerukunan umat beragama serta keikutsertaan dalam keberhasilan pembangunan. Penyuluh Agama mulai disosialisasikan sejak tahun 1985, istilah Penyuluh Agama dipergunakan untuk menggantikan istilah Guru Agama Honorer yang dipakai sebelumnya di lingkungan kedinasan Departemen Agama (saat ini menggunakan istilah Kementerian Agama). Sejak itulah Penyuluh Agama diposisikan sebagai ujung tombak kementerian Agama dalam melaksanakan penerangan agama Islam di tengah pesatnya dinamika perkembangan masyarakat Indonesia.

Dewasa ini, Penyuluh Agama Islam mempunyai peranan yang penting dalam pemberdayaan masyarakat dan pemberdayaan dirinya masing-masing sebagai insan pegawai pemerintah. Dengan kata lain keberhasilan dalam bimbingan dan penyuluhan kepada masyarakat menunjukkan keberhasilan dalam manajemen diri sendiri. Penyuluh Agama Islam sebagai leading sector bimbingan masyarakat islam, memiliki tugas/kewajiban yang cukup berat, luas dan permasalahan yang dihadapi semakin kompleks. Penyuluh Agama Islam 
tidak mungkin berdiri sendiri dalam melaksanakan amanah yang cukup berat ini, ia harus inovatif, bertindak selaku motivator, fasilitator, katalisator dakwah islam dan mediator dari setiap perkara sengketa yang membutuhkan penyelesaian.

Penyuluh Agama Islam mempunyai organisasi untuk memperkuat eksistensi dan profesionalitas penyuluh yang diberi nama POKJALUH (Kelompok Kerja Penyuluh). Secara moril penyuluh juga mempunyai tanggungjawab dalam ikut menekan angka perceraian yang sangat marak terjadi saat ini. Begitu Begitu pula dalam meredam kasus penganiyaan terhadap guru Budi yang dilakukan oleh $\mathrm{MH}$ agar tidak timbul gejolak yang lebih dalam lagi.

\section{PERAN PENYULUH AGAMA DALAM MEDIASI PIHAK SENGKETA}

Penyelesaian sengketa melalui pengadilan sebagai bentuk penyelesaian secara hukum yang bersifat netral (tidak memihak). Namun, pengalaman nyata menunjukkan, penyelesaian melalui pengadilan tidak selalu memberi kepuasan. Selain ongkos, waktu, reputasi dan lain-lain, tidak jarang dijumpai begitu banyak rintangan yang dihadapi menyelesaikan sengketa melaluipengadilan. Bukan saja kemungkinan putusan tidak memuaskan, tetapi suatu kemenangan yang telah ditetapkan itu pun belum tentu secara cepat dapat dinikmati karena berbagai hambatan seperti hambatan eksekusi. Bahkan kemungkinan pada perkara baru, baik dari yang kalah atau dari pihak berkepentingan lainnya. Dalam keadaan seperti itu, putusan pengadilan sekedar sebagai putusan, tetapi tidak berhasil menyelesaikan sengketa. Berbeda dengan penyelesaian sengketa di luar proses peradilan seperti mediasi, bukan semata-mata mencapai putusan, tetapi putusan yang menyelesaikan sengketa.

Menurut Christopher W. Moore mediator memiliki 3 tipe, antara lain: pertama mediator otoritatif dalam proses mediasi terdapat beberapa komponen yang terlibat langsung, yaitu para pihak yang bersengketa (penggugat-tergugat) dan mediator. Ketiga komponen tersebut akan terlibat dalam satu proses interaksi secara timbal balik berdasarkan kepentingan dan pengaruh-pengaruh tertentu. Proses interaksi dan komunikasi bisa terjalin secara teratur dengan panduan penuh mediator atau secara acak di luar kendali mediator. Seorang mediator yang memiliki tipe otoritatif akan mampu mengendalikan komunikasi bahkan dalam beberapa hal dia mampu untuk mempengaruhi hasil akhir dari proses mediasi yang dibangun. Posisi yang dimiliki oleh seorang mediator otoritatif sangat kuat sehingga para pihak terkadang menunjukkan sikap pasrah untuk menyerahkan penyelesaian yang terbaik kepada sang mediator. Kedua, mediator social network mediator yang lahir karena proses hubungan/ jaringan 
sosial atau karena sama-sama berasal dari suatu komunitas tertentu, pada umumnya memiliki keterlibatan secara emosional dengan para pihak. Hubungan sosial terjalin dari berbagai aspek, misalnya karena faktor kelompok dan organisasi tertentu.

Tipe mediator berdasarkan hubungan sosial memiliki kelebihan antara lain lebih mudah untuk menciptakan pola komunikasi yang baik dengan para pihak, karena antara mediator dengan para pihak memiliki karakter dan ciri khas sosial yang sama. Ketiga mediator independent mediator independen merupakan mediator yang sama sekali tidak memiliki keterikatan apapun dengan para pihak, baik karena pribadinya maupun karena sengketa yang sedang dihadapi. Tipe mediator independen ini merupakan tipe yang paling cocok bagi proses perdamaian yang dilakukan dalam proses berperkara di pengadilan, mengingat sifatnya yang independen dan profesional. Mediator independen akan lebih memberikan kenyamanan bagi para pihak dalam mengekspresikan kepentingan-kepentingan kristis pada saat melakukan proses negosiasi dan perundingan (Witanto, 2011: 97-99).

Mediator menurut Fuller memiliki beberapa fungsi, antara lain: Sebagai Katalisator, Fungsi mediator sebagai katalisator harus mampu menciptakan keadaan dan suasana baru dari sebuah pertentangan kearah kondisi koomperatif dalam forum kebersamaan. Tidak terpenting bagi mediator untuk mengetahui siapa yang benar dan siapa yang salah, dan tidak pula untuk mempertajam perbedaan itu dalam forum perundingan. Sebagai Pendidik, Mediator harus mampu menjadi seorang pendidik (educator), yang mampu memberikan arahan dan nasihat menyangkut sikap-sikap yang baik dalam menyelesaikan masalah, mediator harus berusaha untuk memahami kehendak, aspirasi, prosedur kerja, keterbatasan politis dan kendala usaha dari para pihak (Hariyanto, 2017: 69-70).

Sebagai penerjemah hal terpenting dari peranan mediator adalah ketika masing-masing pihak menyampaikan usulan dan konsep penawaran, maka mediator harus mampu menerjemahkan maksud tujuan tersebut kepada pihak lain dengan bahasa lugas dan mudah dimengerti. Ketika salah satu pihak memutuskan untuk sedikit mengalah, maka pihak tersebut harus berani mengambil resiko dengan segala konsekuensinya, sehingga tidak terjadi miss understanding terhadap pengambilan keputusan terpenting dalam proses perundingan.

Sebagai nara sumber fungsi mediator sebagai narasumber bukan berarti bahwa mediator harus serba mengerti, namun setidaknya mediator harus mampu mendayagunakan atau melipat gandakan kemanfaatan sumber-sumber informasi yang tersedia. Berkaitan dengan hal itu, maka mediator harus menguasai 
prosedur dan mekanisme yang berlaku sekaligus memahami tentang materi sengketa yang sedang dihadapi. Walaupun fungsi pokok mediator berbeda dengan penasihat hukum, namun setidaknya mediator dapat memberikan solusi dan penjelasan secukupnya mengenai persoalan-persoalan yang dihadapi (Hariyanto dan Ni'matunnuriyah, 2017: 125).

Sebagai agen realitas ketika dilakukan kaukus akan banyak didapatkan informasi yang bersifat realitas, hal itu harus dikemas menjadi bahan acuan dalam mengelola proses tawar-menawar dan kompromi. Fungsi mediator sebagai agen realitas dapat dilakukan jika mediator dapat menjadi pendengar yang baik dalam proses interaksi verbal. Selain dari pernyataan secara lisan, kondisi realitas dapat disampaikan melalui tulisan-tulisan yang dapat memberikan gambaran tentang sebuah kenyataan (Hariyanto dan Ni'matunnuriyah, 2017: 126).

Sebagai suatu bentuk penyelesaian sengketa dari dan oleh masyarakat, mediasi dapat dipandang sebagai pranata sosial (social institution), bukan pranata hukum (legal institution). Dengan demikian perkembangan atau keberhasilan mediasi sangat tergantung pada sikap sosial masyarakat yang bersengketa. Aturan-aturan hukum yang bersifat mengatur (relegenrecht) dapat dikesampingkan demimencapai kesepakatan mediasi. Tentu saja aturan yang bersifat memaksa (dwingenrecht) tidak dapat dikesampingkan. Kesepakatan mediasi juga tidak dibenarkan kalau bertentangan dengan ketertiban umum, kesusilaan, dan kepentingan umum (Sugiatminingsih, 2009: 135).

Seperti disebutkan diatas, mediasi bukan pranata hukum, melainkan pranata sosial. Karena itu, pekerjaan mediasi bukanlah pekerjaan di bidang hukum, walaupun pekerjaan paling utama menyelesaikan sengketa hukum. Karena itu mediator tidak harus ahli hukum. Alhasil, pekerjaan mediasi terbuka bagi semua orang, termasuk ulama atau tokoh masyarakat begitu pun dengan penyuluh agama selaku muballigh dalam masyarakat. Pendekatan sosial ataukeagamaan dapat menjadi pangkal tolak menyelesaikan sengketa keluarga (baik keluarga kecil atau keluarga besar), tanpa harus menyentuh ketentuan hukum tertentu. Seperti diuraikan di muka, yang harus disentuh dalam mediasi ada rasa keadilan atau kepatutan (Sugiatminingsih, 2009: 137).

Terkait dengan peran Penyuluh Agama Islam sebagai mediator non ajudikasi terhadap pihak sengketa dalam rumah tangga sangat urgen, karena peran mediator memperbaiki hubungan suami istri yang retak dan akan menentukan kelanggengan suatu rumah tangga. Terutama ketika sudah menunjukkan tanda-tanda adanya perselisihan maka disinilah diperlukan peran penyuluh agama sebagai mediator. Dengan dicapainya perdamaian antara suami 
istri dalam sengketa perceraian, bukan keutuhan rumah tangga saja yang dapat diselamatkan tetapi juga kelanjutan pemeliharaan anak dapat dilaksanakan sebagaimana mestinya, agar fungsi mendamaikan dalam perkara perceraian ini dapat dilakukan secara efektif dan optimal, maka sedapat mungkin hakim atau mediator menemukan hal-hal yang melatarbelakangi dari persengketaan yang terjadi (Mustamin, 2014: 123).

Mendamaikan para pihak yang bersengketa merupakan kewajiban kita sebagai ummat manusia dan merupakan pekerjaan mulia sumber hukumnya yaitu firman Allah dalam al Quran:

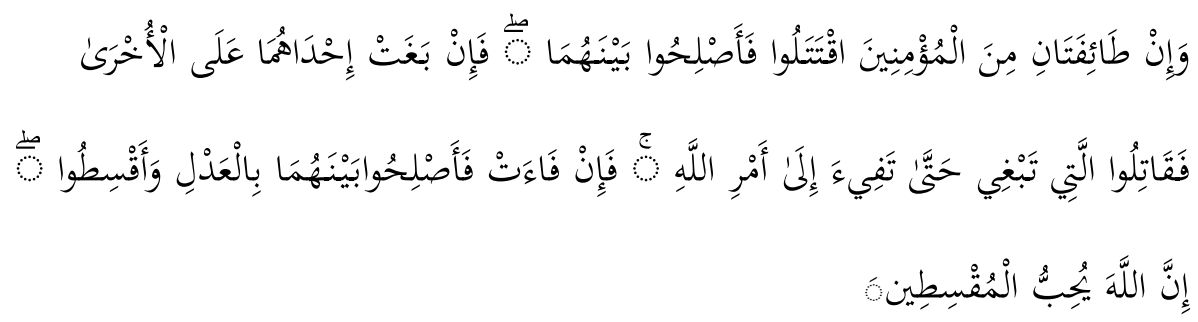

"Dan apabila dua golongan orang yang beriman bertengkar, damaikanlah mereka. Akan tetapi, jika salah satu kedua (golongan) berlaku aniaya (melanggar hak) terhadap yang lain, maka perangilah orang yang menganiaya sampai kembali ke jalan Allah. Akan tetapi, apabila ia telah kembali damaikan keduanya dengan adil, dan bertindaklah benar, sungguh Allah cinta kepada orang-orang yang berlaku adil" (QS. al Hujurat: 9).

Bertitik tolak dari ketentuan ayat di atas, Allah telah mengisyaratkan kepada manusia, apabila terjadi perselisihan atau pertengkaran antara para pihak, maka jalan yang perlu ditempuh adalah harus melakukan upaya perdamaian. Adapun kontribusi yang dilakukan penyuluh agama dalam menyelesaikan perkara sengketa non ajudikasi utamanya dalam rumah tangga yaitu dengan mengajak para pihak yang bertikai untuk berdamai antara lain dengan jalan (Taufiq, 2014: 317), meliputi;

Pertama, Ajakan ini berupa bikmah (kebijaksanaan), yaitu dengan secara bijaksana, akal budi yang mulia, dada yang lapang dan hati yangbersih dan menarik perhatian orang kepada kesepakatan dan solusi.Jika tidak bisa maka dengan mau'idah hasanah yaitupengajaran yang baik, pesan-pesan yang baik, yang disampaikansebagai nasihat kepada para pihak yang bertikai. Jika tidak bisa,maka 
jalan terakhir adalah dengan mujadalah, yaitu berdiskusibersama mereka dengan cara yang lebih baik. Kalau terpaksatimbul perbantahan atau pertukaran fikiran, yang disebut denganpolemik, agar memilih jalan yang sebaik-baiknya (QS. alNahl:125).

Kedua, Meminta klarifikasi dan pertimbangan. Para pihak yang bertikai masing-masing harus memberikan klarifikasiterhadap permasalahan yang ada. Kemudian klarifikasitersebut menjadi pertimbangan dan masukan bagi pihak mediator(QS. al-Mu'min: 28).

Ketiga, Refleksi dan evaluasi. Setelah jelas permasalahan yang ada, maka mediator mengajakpara pihak yang bertikai untuk merefleksikan persoalannya danmelakukan evaluasi bersama guna dicapainya kesepakatanbersama (QS. alBaqarah: 253).

Keempat, Merancang kesepakatan ('azam). Ketika tahap-tahap di atas sudah terlewati, maka perlulah dibuatkesepakatan yang disetujui para pihak yang bertikai dengantekad suara bulat. Para pihak yang bertikai harus percaya bahwarancangan kesepakatan adalah hal yang telah ditimbang dengan matang. Maka hendaknya keputusan itu dijalankan dengan hatibulat, itulah yang bernama 'azam (QS. Muhammad: 21).

Kelima, Pengawasan dan kontrol. Ketika sudah tercapai rancangan kesepakatan, maka para pihak yang bertikai dan mediator harus saling mengawasi dan mengontrol agar apa yang telah dimediasikan benar-benar terealisasidan terlaksana dengan semestinya (QS. al-'Asr: 2-3).

Sebagaimana mengutip pendapat Hamka tentang mediasi, Hamka memandang mereka yang bertikai harus ada yang mengajak berdamai (mediator). Mereka kemudian diajak berdamai, didamaikan dengan baik dan adil, tidak berpihak, melihat dimana kesalahan masing-masing dan diberi nasehat oleh mediator (Taufiq, 2014: 311).

Peran mediasi dalam membangun perdamaian menurut Hamka adalah apa yang ada dalam QS. al-Mumtahanah: 7, yaitu mengokohkan tali persaudaraan (ukbuwwah) dan menimbulkan kesadaran mereka kembali, bahwa mereka semuanya adalah dari satu ummat dan perbedaan suku, bahasa, kulit, pendapat dan kepentingan tidaklah akan membawa pada permusuhan (Taufiq, 2014: 318).

\section{KESIMPULAN}

Dari uraian konsep mediasi di atas, dapat disimpulkan bahwa mediasi adalah sarana terbaik untuk menuju perdamaian. Hal ini dikarenakan mediasi mengedepankan kebersamaan, solusi menang-menang (win-win solution) dan pemberian maaf. Sebagai sarana yang menentukan tujuan perdamaian, maka 
mediasi harus sebaik mungkin. Semakin baik mediasi, semakin baik perdamaian yang akan dicapai. Keuntungan mediasi Penyelesaian sengketa tidak berbelitbelit dan bersifat informal, yang menyelesaikan sengketa adalah pihak sendiri, biaya ringan, jangka waktu penyelesaian pendek, tidak perlu aturan pembuktian. Dalam kasus sengketa rumah tangga peran penyuluh sangatlah penting dalam rangka mengupayakan damai antara pihak yang bersengketa, sehingga keutuhan rumah tangga bisa dirajut kembali serta terhindar dari perselisihan.

\section{DAFTAR PUSTAKA}

Bidang Penais, Zakat dan Wakaf. Petunjuk Teknis Pelaksanaan Jabatan Fungsional Penyulub Agama dan Angka Kreditnya, Biro Kepegawaian Sekretariat Jenderal Departemen Agama Republik Indonesia: 2003.

Hariyanto, Erie 2017. Integrasi mediasi Sebagai Model Penyelesaian Sengketa Perbankan Syariah Masa Depan. Proseding ANCOMS 2017.

Hariyanto, Erie dan Nimatunnuriyah. Advokat Syariah dalam mediasi perkara perceraian menurut Maqashid Syariah, Ulul Albab, Vol. 18 Nomor 1, (2017).

Harahap, Yahya, M. Beberapa Tinjauan Mengenai Sistem Peradilan dan Penyelesaian Sengketa. Bandung : PT. Citra Aditya Bakti, 1997.

Jacqueline, Halley, M. Nolan.Alternatife Despute Reso lution (ADR). USA: West Publishing, 1992.

Jamil, Mukhsin, M. (ed.) "Pengantar Mediasi: Teori dan Praktek," dalam Mengelola Konflik Membangun Damai, Cet. 1, Semarang: WMC IAIN Walisongo, 2007.

Muhadjir, Noeng. Metode Penelitian Kualitatif, Yogyakarta: Rake Sarasin, 1996.

Mustaming, Tinjauan Yuridis Penyelesaian Sengketa di Pengadilan Agama Melalui Proses Mediasi. Al-Abkam Vol. 14, No. 2 Agustus 2014.

Sugiatminingsih, Mediasi Sebagai Media Alternative Penyelesaian Sengketa di Luar Pengadilan, Jurnal Nomor 2Vol. 12 (2009), Juli - Desember. 
Suryabrata, Sumadi. 2005, Metode Penelitian, Jakarta: PT Raja Grafindo Persada.

Soekamto, Soerjono, Pengantar Penelitian Hukum, Jakarta: UI Press, 1988.

Taufiq, Imam. Membangun Damai Melalui Mediasi: Studi terhadap Pemikiran Hamka dalam Tafsir Al-Azhar, Al-Tabrir, Vol. 14 Nomor 2, (2014) Mei.

Usman, Rachmadi. Mediasi di Pengadilan dalam Teori dan Praktik. Cet. 1, Jakarta: Sinar Grafika, 2012.

Witanto, D. Y. Hukum Acara Mediasi, Bandung: Alfabeta, 2011. 